\title{
DEMOKRASI DAN PEMILU INDONESIA 2019
}

\author{
Achmad Hasfa Jauhari \\ Prodi Kesehatan Masyarakat
}

lik STRADA Indonesia

\section{Kresekjr276@gmail.com}

\begin{abstract}
Abstrak
Tulisan ini membahas tantangan konsolidasi demokrasi dalam pemilu presiden (pilpres) 2019. Pembangunan demokrasi Indonesia sebagaimana tercermin dari pilpres masih mengalami banyak masalah. Pendalaman demokrasi belum terwujud dengan baik karena pilar-pilar demokrasi yang menjadi faktor penguat konsolidasi demokrasi belum efektif. Pilpres 2019 belum mampu menghasilkan suksesi kepemimpinan yang baik dan belum mampu pula membangun kepercayaan publik. Hal tersebut bisa dilihat Â dari munculnya kerusuhan sosial setelah pengumuman hasil rekapitulasi pilpres oleh Komisi Pemilihan Umum (KPU). Satu kandidat menolak hasil pemilu. Adalah jelas pilpres belum selesai. Sekarang Mahkamah Konstitusi (MK) menjadi penentu akhir hasil pilpres karena dua kandidat mengklaim sebagai pemenang pilpres.
\end{abstract}

Kata Kunci: Pendalaman Demokrasi, Pemilu Presiden,

A. Latar belakang

Demokrasi telah menjadi arus utama negara-negara modern. Prasyarat negara demokrasi modern adalah penyelenggaraan Pemilu. Pemilu merupakan mekanisme utama dan prasyarat bagi demokrasi perwakilan. Pemilu diselenggarakan untuk mewujudkan tujuan demokrasi, yaitu pemerintahan dari, oleh dan untuk rakyat. Untuk mencapai tujuan tersebut, penyelenggaraan pemilu harus mencerminkan nilainilai demokrasi.

Sistem demokrasi perwakilan bertujuan agar kepentingan dan kehendak warga negara tetap dapat menjadi bahan pembuatan keputusan melalui orang-orang yang mewakili mereka. Di dalam gagasan demokrasi perwakilan, kekuasaan tertinggi (kedaulatan) tetap di tangan rakyat, tetapi dijalankan oleh wakil-wakil rakyat yang dipilih oleh rakyat sendiri.

Demokrasi adalah bentuk atau mekanisme sistem pemerintahan suatu negara sebagai upaya mewujudkan kedaulatan rakyat (kekuasaan 
warganegara) atas negara untuk dijalankan oleh pemerintah negara

tersebut.Salah satu pilar demokrasi adalah prinsip trias politica yang membagi ketiga kekuasaan politik negara (eksekutif, yudikasi dan legislatif) untuk diwujudkan dalam tiga jenis lembaga negara yang saling lepas (independen) dan berada dalam peringkat yang sejajar satu sama lain. Kesejajaran dan b ketiga jenis lembaga negara ini diperlukan agar ketiga lembaga negara ini bisa saling mengawasi dan saling mengontrol berdasarkan prinsip checks and balances.

Gagasan pemilihan Presiden dan Wakil Presiden secara langsung lahir dan di implemetasikan dalam sistem politik Indonesia dengan latar belakang potret buram tirani kekuasaan pada rezim orde lama dan orde baru. Pada masa orde lama di bawah kepemimpinan Presiden Soekarno pelanggaran terhadap konstitusi terjadi tatkala Soekarno menerima pengangkatan dirinya sebagai Presiden seumur hidup menyusul dikeluarkannya TAP MPRS yang mengatur bahwa,: "Dr. Ir Soekarno (Mr. Soekarno), Pemimpin Besar Revolusi Indonesi, yang sekarang Presiden Republik Indonesia, dengan rahmat Tuhan Yang Maha Esa dengan ini menjadi Presiden Indonesia seumur hidup".

B. Kasus dan masalah

pemanfaatan aparatur dan aset pemerintah untuk mendukung kemenangan pihak tertentu membuat pelaksanaan pemilu tidak berjalan adil. Menurutnya, partai politik telah menjadi kepentingan perorangan dan kelompok.

Kewajibannya seperti kaderisasi yang tidak memiliki visi secara jelas. Selain itu, ia mengamati, keberpihakan menjadi hal biasa.

C. Tinjauan pustaka

1. Pemilihan Umum

Pengisian lembaga perwakilan dalam praktek ketatanegaraan lazimnya dilaksanakan melalui Pemilihan Umum.Pasca perubahan amandemen UUD 1945, semua anggota lembaga perwakilan dan bahkan presiden serta Kepala Daerah dipilih dengan mekanisme Pemilihan Umum. Pemilihan umum menjadi agenda yang diselenggarakan secara berkala di Indonesia.

Ibnu Tricahyo (2009:6), mendefinisikan Pemilihan Umum sebagai berikut:"Secara universal Pemilihan Umum adalah instrumen mewujudkan kedaulatan rakyat yang bermaksud membentuk pemerintahan yang absah serta sarana mengartikulasikan aspirasi dan kepentingan rakyat". Definisi di atas menjelaskan bahwa pemilihan umum merupakan instrumen untuk mewujudkan kedaulatan rakyat, membentuk pemerintahan yang sah serta sebagai sarana mengartikulasi aspirasi dan kepentingan rakyat.Negara Indonesia mengikutsertakan rakyatnya dalam rangka penyelenggaraan negara.Kedaulatan rakyat dijalankan oleh wakil rakyat yang duduk dalam parlemen dengan sistem perwakilan (representative democracy) atau demokrasi tidak langsung (indirect democracy). Wakil-wakil rakyat ditentukan sendiri oleh rakyat melalu Pemilu (general election) secara berkala agar dapat memperjuangkan aspirasi rakyat.

Soedarsono (2005:1)mengemukakan bahwa yang dimaksud dengan pemilihan umum adalah syarat minimal bagi adanya demokrasi dan diselenggarakan dengan tujuan memilih wakil rakyat, wakil daerah, presiden untuk membentuk pemerintahan demokratis". 
Penjelasan di atas menyebutkan bahwa pemilihan umum merupakan syarat minimal adanya demokrasi yang bertujuan memilih wakil-wakil rakyat, wakil daerah, presiden untuk membentuk pemerintahan demokratis. Kedaulatan rakyat dijalankan oleh wakil-wakil rakyat yang duduk di dalam lembaga perwakilan.Kedaulatan rakyat atas penyelenggaraan pemerintahan dijalankan oleh presiden dan Kepala Daerah yang juga dipilih secara langsung. Anggota legislatif maupun Presiden dan Kepala Daerah karena telah dipilih secara langsung, maka semuanya merupakan wakil-wakil rakyat yang menjalankan fungsi kekuasaan masing-masing. Kedudukan dan fungsi wakil rakyat dalam siklus ketatanegaraan yang begitu penting dan agar wakil-wakil rakyat benarbenar bertindak atas nama rakyat, maka wakil rakyat tersebut harus ditentukan sendiri olehrakyat, yaitu melalui pemilihan umum.

Menurut Jimly Asshidiqqie (2006:169-171)pentingnya penyelenggaraan Pemilihan Umum secara berkala tersebut dikarenakan beberapa sebab diantaranya sebagai berikut:

a. pendapat atau aspirasi rakyat cenderung berubah dari waktu ke waktu;

b. kondisi kehidupan masyarakat yang dapat juga berubah;

c. pertambahan penduduk dan rakyat dewasa yang dapat menggunakan hak pilihnya;

d. guna menjamin regulasi kepemimpinan baik dalam cabang eksekutif dan legislatif.

Berdasarkan pernyataan di atas bahwa beberapa sebab pentingnya pemilihan umum diantaranya adalah aspirasi rakyat cenderung berubah, kondisi kehidupan rakyat berubah, pertambahan penduduk dan regulasi kepemimpinan.Pemilihan umum menjadi sarana untuk menyalurkan aspirasi rakyat. Kondisi kehidupan rakyat yang cenderung berubah memerlukan adanya mekanisme yang mewadahi dan mengaturnya yaitu melalui proses pemilihan umum. Setiap penduduk dan rakyat Indonesia yang telah dewasa memiliki hak untuk menggunakan hak pilihnya dalam pemilihan umum. Regulasi kepemimpinan baik cabang eksekutif maupun legislatif akan terlaksana secara berkala dengan adanya pemilihan umum.

\section{Teori Demokrasi}

Secara umum demokrasi dipahami sebagai suatu bentuk pemerintahan atau sistem politik yang didasarkan atas kepentingan rakyat. Sebagai pemegang kedaulatan, rakyat dilibatkan dalam segala aktifitas politik dan pemerintahan, baik dalam proses pengambilan keputusan, pelaksanaan kebijakan maupun pengawasan. Melibatkan rakyat secara maksimal memungkinkan terciptanya pemerintahan dari rakyat, oleh rakyat, dan untuk rakyat.

Namun, sampai saat ini tidak ada pengertian yang dapat mendefinisikan secara lengkap tentang demokrasi. Prof. Juanda, dalam buku "Hukum Pemerintahan Daerah" mengutip padangan beberapa ahli tentang demokrasi, seperti Francois Venter yang menyatakan bahwa "Everyone knows what democracy is, but nobody can define it to general satisfaction." (setiap orang tahu apa demokrasi, tetapi tidak seorangpun yang dapat mendefinisikan untuk memuaskan masyarakat). Begitu pula yang dipetik dari Mac Gregor Burn yang menyatakan bahwa "Democracy like liberty, equality, and justice is hard to define precisely" (Demokrasi seperti kemerdekaan, kesamaan, dan keadilan adalah sulit untuk didefinisikan). 
Meskipun sulit untuk didefiniskan, Dilys M. Hill mencoba mengartikan demokrasi yang dipetik oleh Prof. Juanda, yaitu "The definition of democracy, on the other hand, is concerned with the national political sistem based on citizen participation majority rule, consultation and discussion and responsibility of leaders to lead". (dengan kata lain demokrasi diartikan sebagai sistem politik nasional yang didasarkan pada partisipasi warga negara, peraturan mayoritas, konsultasi dan diskusi dan pertanggungjawaban pemimpin terhadap pemilih). Sedangkan, Rod Hague dan Martin Harrop mendefinisikan demokrasi ditinjau dari asal katanya dengan demikian "the word itself comes from the Greek "demokratia", meaning rule (kratos) by the people (demos. Thus democracy- in its literal and riches sense -refers not to election of the rulers by the ruled but to denial of any separation between the two." (Demokrasi berasal dari kata Yunani "demokratia" yang artinya kekuasaan atau aturan (kratos) oleh rakyat (demos). Jadi demokrasi dalam arti harfiah adalah banyak makna, yaitu tidak hanya pemilihan terhadap pemimpin oleh masyarakat tetapi penyangkalan pemisaham terhada keduanya, yang menyatakan bahwa rakyat merupakan kesatuan individu sehingga kekuasaan rakyatlah yang tertinggi, yang mana memberikan sebagian haknya pada penguasa untuk kepentingan bersama. Penguasa dipilih berdasarkan kehendak rakyat. Dengan pernyataan-pernyataan di atas dapat disimpulkan, meskipun demokrasi berarti kedaulatan tertinggi berada di tangan rakyat, tetapi tidak serta merta rakyatlah yang menjalankan roda pemerintahan, melainkan rakyat turut berpartisipasi dengan memilih wakilnya dalam roda pemerintahan yaitu sebagai eksekutif dan juga legislative, yang diaktualisasikan melalui pemilihan umum. Sehingga, dalam kewenangannya mengelola pemerintahan, pemerintah tidak dapat sewenang-wenang dalam memutuskan atau membuat kebijakan tetapi perlu ada konsultasi, diskusi, serta pertanggung jawaban terhadap pemilih, yaitu rakyat. Secara singkat Abraham Lincoln mengembangkan demokrasi menjadi sebuah filosofi pemerintahan, yaitu "government of the people, by the people, and for the people." (pemerintahan dari rakyat, oleh rakyat, dan untuk rakyat).Prof. Jimly Asshiddiqie dalam makalahnya, mengatakan bahwa "Kelemahan demokrasi adalah antara lain terlalu mengutamakan kuantitas suara mayoritas, bukan kualitas keadilan." Sehingga menurut Asshiddiqie.

\section{Kesimpulan}

Berdasarkan pembahasan diatas maka dalam penulisan karya ilmiah ini dapat disimpulkan bahwa Pertama, gagasan Pemilihan Umum serentak jikalau ditinjau melalui metode original intent maupun ilmu tafsir sejarah (historis) maka kedudukannya memiliki dasar keabsahan yuridis konstitusional sebagai upaya untuk menggeser era transisi demokrasi menuju kearah konsolidasi demokrasi yang menekankan pada upaya untuk meminimalasisasi praktikpraktik buruk sistem demokrasi langsung yang transaksional, koruptif, serta memiliki kecenderungan untuk melembagakan politik klan dalam dinamika sistem politik ketatanegaraan di Indonesia. Kedua dalam ranah praktis justru kontra produktif dan inkonsisten terhadap upaya penegakan hukum, memperkuat sistem presidensil serta supremasi konstitusi karena konstitusionalitas bersyarat sebagaimana termaktub didalam Putusan cenderung menghambat terwujudnya konsolidasi demokrasi dalam momentum 
Pemilihan umum di tahun 2014.

E. Daftar pustaka

Gaffar, J. M. (2013). Demokrasi dan PEMILU di Indonesia.

Sorik, S. (2019). Penataan Demokrasi dan Pemilu di Indonesia Pasca

Reformasi. Jurnal Penelitian Politik, 16(1), 101-107.

https://dspace.uii.ac.id > handlePDF

Arrsa, R. C. (2016). Pemilu Serentak dan Masa Depan Konsolidasi

Demokrasi. Jurnal Konstitusi, 11(3), 515-537.

https://www.gatra.com > detail > news

Persoalan Demokrasi dalam Pemilu 2019 | Politik - Gatra.com

https://repository.uksw.edu > ...PDF

http://eprints.umm.ac.id > ...PDF

Siyoto, S., \& Sodik, MA (2015). Dasar metodologi penelitian . Penerbitan Media Literasi. 